\title{
43. TETRAPYRROLE PIGMENTS IN CRETACEOUS SEDIMENTS FROM THE BAY OF BISCAY, IPOD LEG 48, HOLE 402A
}

\author{
Earl W. Baker and Susan E. Palmer, Department of Geology, Florida Atlantic University, Boca Raton, Florida
}

\section{INTRODUCTION}

Eight core samples, of Albian to Aptian age from Hole $402 \mathrm{~A}$ drilled on the mid-continental slope of the Bay of Biscay, were analyzed for chlorophyll degradation products. Pigment concentrations were surprisingly low for these particular Cretaceous black shales and contrast with the large quantities of pigments found in Cretaceous sediments from the Cape, Angola, and Cape Verde basins off the west coast of Africa, where average pigment concentrations were $5.5 \mu \mathrm{g} / \mathrm{g}(\operatorname{Leg} 41)$ and $8.0 \mu \mathrm{g} / \mathrm{g}(\operatorname{Leg} 40)$. Small amounts $(0.13 \mu \mathrm{g} / \mathrm{g}$ average value) of chlorins and nickel porphyrins were found in each sample; these values were relatively low with respect to organic carbon contents which ranged from 0.4 to 1.7 per cent for adjacent or nearby core samples. The type of depositional regime (redox and water depth) and amount of weathered terrestrial detrital input suggest themselves as important factors leading to the quality and quantity of preserved organic matter, thus accounting for the differences between yields of extractable pigments from Bay of Biscay Cretaceous sediments and yields from basins off the West African coast.

The pigment distribution was similar to that of AlbianAptian core samples, from Leg 47B, Hole 398D (Vigo Seamount, off the coast of northern Portugal) but the sediments are only at 255-465 meters depth of burial (subbottom) at Hole 402A as compared with 1070-1550 meters for Hole 398D (Palmer and Baker, in press). In both cases, only small amounts $(\approx 0.1 \mu \mathrm{g} / \mathrm{g}$ average total pigment concentration) of chlorins and nickel porphyrins were found. Typically, chlorins were one-tenth as abundant as the nickel porphyrins and ranged from 0.001 to $0.003 \mu \mathrm{g} / \mathrm{g}$. Presently observable similarities among the sediments, proposed depositional regimes, and subsidence histories, in addition to pigment distributions, suggest original similarities of Albian-Aptian sediments in Holes 398D and 402A. The presence of chlorins and the predominance of DPEP-type nickel porphyrins are indicative of a mild geothermal history in both localities.

\section{EXPERIMENTAL}

Samples collected for organic geochemical studies were thawed for a three-week period while in transit (storage temperature $=2-4^{\circ} \mathrm{C}$ ) from ship to DSDP, Scripps Institution of Oceanography, after which the cores were stored frozen until the time of analysis. One hundred grams (wet weight) of sediment were extracted with acetone:methanol (9:1) in a ballmill until the extract was clear. Type and quantity of pigment was determined by spectrophotometry using a Perkin-Elmer Model 575 scanning spectrophotometer. Separations of chlorins from nickel porphyrins were made by partition between $20 \% \mathrm{HC1}$ (by wt) and ethyl ether. Nickel porphyrins were purified by chromatography over Alumina Grade III with cyclohexane:benzene (1:1). Low concentrations of purified pigment precluded mass spectrometric analyses, thus interpretations are based on spectrophotometric data alone.

\section{RESULTS AND DISCUSSION}

Electronic spectrometric data, along with geologic data, are presented in Table 1 . Trace amounts ( 0.001 to 0.003 $\mu \mathrm{g} / \mathrm{g}$ ) of chlorins were present in six of the eight samples whereas nickel porphyrins were present in seven samples at five to ten times the chlorin concentration ( 0.005 to 0.02 $\mu \mathrm{g} / \mathrm{g}$ ). The low amount of extractable organic matter, observable from the quality of the crude extracts, markedly contrasts with the relatively high organic carbon content (0.4 to $1.7 \%)$. In several studies in the past, the amount of extractable pigment has roughly paralleled changes in total organic carbon (see, for example, Baker et al., 1978b, d) and Baker and Palmer, in press). Using these studies for comparative purposes, an average amount of pigment would be $0.2 \mu \mathrm{g} / \mathrm{g}$ for a similar type of sediment with approximately 1 per cent organic carbon. Thus, an order of magnitude or greater needs to be accounted for.

A discrepancy between extractable pigment and organic carbon content may be attributed most reasonably to the type of organic matter present. If the organic matter were primarily terrestrial detritus that had been oxidized through weathering processes or subaerial exposure, the amount of extractable organic matter may be low. Thermal alteration of organic-rich shales also results in divergence between organic carbon and amount of pigment extract (Baker et al., $1978 \mathrm{~b}, \mathrm{c})$; however, this latter explanation probably does not apply to the Hole 402A samples.

The chlorins were too low in concentration for separation or purification and therefore only their presence or absence is noted in Table 1. Because, however, nickel porphyrins were present in higher concentrations, slightly more refined data were obtained. Ratios of the visible light absorbance bands, $\alpha(553 \mathrm{~nm})$ and $\beta(518 \mathrm{~nm})$, were calculated for each nickel porphyrin isolate (Table 2). Contrary to earlier studies, the ratios do not trend smoothly with increasing depth. For example, Cores 402A-13, -24 , and -35 had $\alpha / \beta$ ratios of $1.9,1.5,1.7$, respectively, whereas Cores $402 \mathrm{~A}$ $15,-21,-30$, and -33 had values of $2.2,2.4,2.9$, and 2.3 , respectively. These variations could be indicative of the presence of porphyrins supplied by different sources of organic matter or of different rates of influx of organic matter. The shipboard party attributed influxes of land-derived detrital organic matter to the deposition of these Aptian-Albian black shales. They also noted a rhythmic alternation of de- 
TABLE 1

Tetrapyrrole Pigment Data From Leg 48, Hole 402A

\begin{tabular}{|c|c|c|c|c|c|c|c|c|c|c|c|}
\hline Section & Geologic Age $^{\mathrm{a}}$ & $\begin{array}{l}\text { Lithologic } \\
\text { Description }\end{array}$ & $\begin{array}{l}\text { Depth of } \\
\text { Burial }(\mathrm{m})^{\mathrm{a}}\end{array}$ & $\begin{array}{l}\text { Organic Carbon }{ }^{\mathrm{a}} \\
\text { (\% by wt) }\end{array}$ & $\begin{array}{c}\text { Pigment } \\
\text { Concentration } \\
(\mu \mathrm{g} / \mathrm{g})\end{array}$ & \multicolumn{5}{|c|}{$\begin{array}{l}\text { Electronic Spectrum } \\
\text { (nanometers) }\end{array}$} & Pigment Type \\
\hline $402 \mathrm{~A}-13-3$ & $\begin{array}{l}\text { Early Cretaceous } \\
\text { (Late Albian) }\end{array}$ & Calc. dark gray mud & $251-260.5$ & 0.5 & $\begin{array}{l}0.001 \\
0.01\end{array}$ & 395 & 516 & 554 & & 658 & $\begin{array}{l}\text { Chlorin } \\
\text { Nickel porphyrin }\end{array}$ \\
\hline $402 \mathrm{~A}-15-1$ & Late Albian & Calc. dark gray mud & $270-279.5$ & 1.1 & $\begin{array}{l}0.001 \\
0.01\end{array}$ & 393 & 515 & 552 & & 658 & $\begin{array}{l}\text { Chlorin } \\
\text { Nickel porphyrin }\end{array}$ \\
\hline $402 \mathrm{~A}-18-1$ & Late Aptian & Calc. black mud & $298.5-308$ & 1.3 & 0.001 & & & & & 658 & Chlorin \\
\hline $402 \mathrm{~A}-21-1$ & Late Aptian & Calc. black mud & $327-336.5$ & 1.3 & $\begin{array}{l}0.002 \\
0.02\end{array}$ & 396 & 518 & 553 & 604 & 658 & $\begin{array}{l}\text { Chlorin } \\
\text { Nickel porphyrin }\end{array}$ \\
\hline $402 \mathrm{~A}-24-1^{\mathrm{C}}$ & Late Aptian & Calc. black mud & $355.5-365$ & 1.7 & 0.02 & 394 & 508 & 552 & & & Nickel porphyrin \\
\hline $402 \mathrm{~A}-30-1^{\mathrm{C}}$ & Late Aptian & Calc. black mud & $412.5-422$ & 1.5 & $\begin{array}{l}0.001 \\
0.02\end{array}$ & 395 & 514 & 552 & $(600)$ & $(660)$ & $\begin{array}{l}\text { Chlorin } \\
\text { Nickel porphyrin }\end{array}$ \\
\hline $402 \mathrm{~A}-33-1^{\mathrm{c}}$ & Late Aptian & Calc. dark gray mud & $441-450.5$ & 0.9 & 0.01 & 394 & 515 & 553 & & & Nickel porphyrin \\
\hline $402 \mathrm{~A}-35-4$ & Early Aptian & Dark gray shale & $460-469.5$ & 0.4 & $\begin{array}{l}0.003 \\
0.005\end{array}$ & $\begin{array}{l}(400) \\
398\end{array}$ & 518 & 556 & $(590)$ & 663 & $\begin{array}{l}\text { Chlorin } \\
\text { Nickel porphyrin }\end{array}$ \\
\hline
\end{tabular}

${ }^{\mathrm{a}}$ Data obtained from DSDP, Scripps Institution of Oceanography.

bIndividual pigment yields calculated by using the following molar extinction coefficients: pheophytin "a" $=63700$ at $660 \mathrm{~nm}$ and nickel porphyrin $=34820$ at $550 \mathrm{~nm}$.

${ }^{\mathrm{c}}$ Cores 402A-24 and - 30 contained fragments of ammonite shell which still retained a pearly luster; cores $402 \mathrm{~A}-30$ and -33 contained fragments of shell and shell molds of the pectin, Propeamussium sp. 
TABLE 2

a/ $\beta$ Ratios of

Nickel Porphyrins

Isolated From Leg

48, Hole 402A

Samples

\begin{tabular}{ll}
\hline Core-Section & $a / \beta$ \\
\hline $13-3$ & 1.9 \\
$15-1$ & 2.2 \\
$21-1$ & 2.4 \\
$24-1$ & 1.5 \\
$30-1$ & 2.9 \\
$33-1$ & 2.3 \\
$35-4$ & 1.7 \\
\hline
\end{tabular}

posits which might have been caused by changes in the rate of terrestrial input (Shipboard Party-48, 1976).

Previous studies have shown that $\alpha / \beta$ ratios for nickel porphyrins can be used as indicators of degree of thermal stress (Baker et al., 1978c). With increasing thermal treatment, the ratio increases from approximately 2.0 to 3.0 or higher. An increase in the ratio results from the amount of enrichment of the etio porphyrin component formed from the rupture of the isocyclic ring which is characteristic of DPEP (deoxophylloerythroetioporphyrin), for structure see Baker et al., (1978c). Thus a value of 2.0 or slightly higher would be indicative of a mixture of relatively unstressed DPEP-type nickel porphyrins. As shown in Table 2 , half of the samples contained porphyrins with $\alpha / \beta$ ratios of approximately 2.0 . These data, coupled with the observation of chlorins in the same samples, are indicative of a mild geothermal history. Ratios of approximately 1.5 have been observed for unidentified pigments believed to be oddmolecular weight metalloporphyrins, but ratios greater than three have been observed for dealkylated nickel etio porphyrins.

In summary, mild thermal diagenetic histories for organic matter in Aptian-Albian sediments for Holes $402 \mathrm{~A}$ and $398 \mathrm{D}$, now at contrasting depths of 225 to 465 meters and 1070 to 1550 meters, are suggested by the distribution of chlorins and nickel porphyrins in both sites. The depositional regimes and quality of organic matter may have also been quite similar during Aptian-Albian times. The ideas concerning the shallowness of the depositional environment, the amount of land-derived detrital organic matter, and tectonic history of the Bay of Biscay region discussed by the shipboard party provide the basis for this interpretation (Shipboard Party-47 and 48, 1976).

The depositional environment of this region during the Early Cretaceous must have contrasted markedly with that of the South Atlantic. Although evidence of terrestrially derived material was found in samples from the Cape and Angola basins, deposition was in a reducing environment (Bolli, Ryan, et al., 1978). The reducing environment arose because of restricted oceanic circulation which is believed to have persisted until late Aptian (Cape Basin) and Santonian times (Angola Basin) at which time the South Atlantic began to open. In contrast, in the Bay of Biscay region, rifting had already begun during the Early Cretaceous (Shipboard party-Leg 48, 1976).

\section{ACKNOWLEDGMENTS}

This research was supported by the Oceanography Section of the National Science Foundation, Grants OCE 74-12438 A02 and OCE 77-07273. The authors thank Dr. Carol C. Jones of the Field Museum of Natural History, Chicago, for her help with the identification of fossil material and Mr. Gerard DeMott for his help with sample work up. The authors also wish to thank William E. Harrison of the Oklahoma Geological Survey, Norman, Oklahoma, for his review of this manuscript.

\section{REFERENCES}

Baker, E.W. and Palmer, S.E., in press. Chlorophyll diagenesis in IPOD Leg 47A, Site 397 core samples. In Ryan, W.B.F., von Rad, U., et al., Initial Reports of the Deep Sea Drilling Project, v. 47, Part 1: Washington (U.S. Government Printing Office).

Baker, E. W., Huang, W. Y., Rankin, J. G., Castaño, J. R., Guinn, J.R., and Fuex, A.N., 1978a. Electron paramagnetic resonance study of thermal alteration of kerogen in deep-sea sediments by basaltic sill intrusion. In Lancelot, Y. Seibold, E., et al., Initial Reports of the Deep Sea Drilling Project, v. 41: Washington (U.S. Government Printing Office), p. 839 848.

Baker, E.W., Palmer, S.E., and Huang, W.Y., 1978b. Chlorin and porphyrin geochemistry of DSDP Leg 40 sediments. In Bolli, H. M., Ryan, W. B. F., et al., Initial Reports of the Deep Sea Drilling Project, Supplement to Volumes 38, 39, 40 and 41: Washington (U.S. Government Printing Office), p. 639-647.

Baker, E.W., Palmer, S.E., and Huang, W.Y., 1978c. Intermediate and late diagenetic tetrapyrrole pigments, Leg 41: Cape Verde Rise and Basin. In Lancelot, Y., Seibold, E., et al., Initial Reports of the Deep Sea Drilling Project, v. 41: Washington (U.S. Government Printing Office), p. 825-838.

Baker, E.W., Palmer, S.E., and Huang, W.Y., 1978d. Miocene and Cretaceous tetrapyrrole pigments from Leg 44, Site 391. In Benson, W. E., Sheridan, R. E., et al., Initial Reports of the Deep Sea Drilling Project, v. 44: Washington (U.S. Government Printing Office), p. 639-644.

Bolli, H. M., Ryan, W. B. F., et al., 1978. Initial Reports of the Deep Sea Drilling Project, v. 40: Washington (U.S. Government Printing Office).

Palmer, S.E. and Baker, E.W., in press. Tetrapyrrole pigments from IPOD Leg 47B, Hole 398D. In Ryan, W.B.F., Sibuet, J.C., et al., Initial Reports of the Deep Sea Drilling Project, v. 47, Part 2: Washington (U.S. Government Printing Office).

Shipboard party-Leg 47, 1976. Passive continental margin. Geotimes, v. 21 , no. 10, p. 21-24.

Shipboard party-Leg 48, 1976. Glomar Challenger sails on Leg 48 , Geotimes, v. 21 , no. 12, p. 19-23. 